\title{
NEW CHALLENGES IN ASEAN REGIONAL MARKET: INTERNATIONAL TRADE FRAMEWORK ON HALAL STANDARD
}

\author{
Eva Johan \\ PhD Student, Law and Governance Group, Wageningen University \& Research, the Netherlands \\ Faculty of Law, Sultan Ageng Tirtayasa University \\ Jl. Raya Jakarta Km. 4 Pakupatan, Serang - Banten, Indonesia \\ E-mail: eva.johan@wur.nl, evajohan@untirta.ac.id
}

\begin{abstract}
The use of non-tariff protection increased during 1980s. One of Non-tariff measures which have been deployed by countries is safety and health standards/technical specifications. In many Muslim countries, Halal standard has essential part in protecting consumer rights. National labeling laws must seek a balance between labeling requirements and certification to minimize barriers to the free trade. The problem is every nation has own Halal Standard. This could result trade dispute among parties since import product cannot enter local market based on different Halal Standard. This situation remains as non-tariff barriers to free trade. By capturing the differences of Halal Standard in some ASEAN countries, the result shows some challenges rise for ASEAN to create one unified Halal Standard framework in order to gain strong ASEAN single market in the future.
\end{abstract}

Keywords: non-tariff barriers, halal, standard, international trade.

Abstrak

Pengenaan aturan hambatan non-tarif mulai meningkat sejak tahun 1980-an. Salah satu tindakan nontarif yang diperkenankan menurut Hukum WTO dan selama ini dipraktekkan oleh Negara adalah melalui pengenaan aturan keamanan, standar kesehatan atau tindakan teknis lainnya kepada produk impor. Pada Negara yang mayoritas berpenduduk muslim, Standar Halal memiliki bagian penting dalam melindungi hak-hak konsumen. Hukum Nasional yang mengatur Standar Halal harus memenuhi ketentuan Hukum WTO, sehingga diharapkan standar halal nasional tidak akan melanggar aturan perdagangan internasional. Permasalahannya adalah setiap Negara memilki aturan Standar Halal sendiri. Hal ini menimbulkan sengketa perdagangan karena produk impor tidak dapat masuk pasar Negara akibat standar halal yang berbeda. Standar Halal kemudian dianggap sebagai hambatan bagi perdagangan bebas. Dengan menggambarkan Standar Halal yang berlaku di beberapa Negara ASEAN, hasilnya menunjukkan beberapa tantangan bagi Asean untuk mewujudkan satu kerangka Standar Halal yang sama guna mencapai potensi Pasar tunggal ASEAN yang kuat.

Kata kunci: hambatan non-tarif, halal, standar, perdagangan internasional.

\section{Introduction}

The Policy of world market integration puts many developing countries in a situation of global competition they were not prepared for. This situation leads countries to engage in bilateral or regional agreements, and free trade agreements at regional level is more beneficial for them in certain sectors. ASEAN is one big regional agreement which Indonesia is a part of.

The use of non-tariff protection in International Trade increased during 1980s, mostly as a substitute for the tariffs which were outlawed, and impact of World Trade Organization policy. One of Non-tariff measures which have been deployed by both developed and developing countries is safety and health standards/ technical specifications.

In most Muslim countries or countries with a Muslim majority, Halal standard having essential part in protecting consumer rights. Muslims believe food they consume will determine how generation quality and civilization in the future. Halal food will produce generation 
and civilization with halal lifestyle. Otherwise, Haram food will result haram generation and civilization in the future. ${ }^{1}$

The Halal term refers to food and beverages that are permissible for use and consumption by Muslims. The term comes from Arabic meaning Lawful, and opposite to this meaning is Haram or prohibited. ${ }^{2}$ Muslim consumers recognized Halal product by identifying the halal certification or halal logo in product packages.

Halal certification is not merely to protect Muslim consumers from un-halal product but also to take a role in strengthening local competitiveness for halal product in international market. ${ }^{3}$ The Muslim consumers have sufficient knowledge on what halal product is, ${ }^{4}$ at least by looking for halal label on the product package. Food labelling frameworks aim to regulate different interest which range of human health, religion and consumers' rights to international trade. As much as labeling, halal logo has significant portion in Muslim purchase. ${ }^{5}$ Therefore, halal certification has become highly crucial to fulfill the firms. ${ }^{6}$ National labelling laws and logo must seek a balance between labelling requirements and certification to minimize barriers to the free trade.

Muslims are very selective in choosing and buying food and other product in the market. They will not buy goods or product that is doubtful. Religion has influence Muslim activiti-

Sulhan Abu Fitra, "Makanan Menentukan Kualitas Generasi dan Peradaban", Journal Halal, Vol. XVIII No. 113, Mei-Juni 2015, p. 32.

2 Abdul Ghafar Ismail and Mohd Ali Mohd Noor, "Halal Finance and Halal Foods: Are They Falling Apart?," Journal Acta Universitatis Danubius Economica, Vol. 12 No. 3, 2016, p. 113

3 Abdurrachman Sabran and Nuradi Noeri, "Sertifikasi Halal", Journal AKSES, Vol. 33, Agustus 2015, p. 3.

4 Imam Salehudin, "Halal Literacy: A Concept Exploration and Measurement Validation", ASEAN Marketing Journal, Vol.II - No. 1, June 2010, p.12.

5 Nazlida Muhamad, Vai Shiem Leong, Normalisa Md Isa, "Does the country of origin of a halal logo matter? The case of packaged food purchases", Journal Review of International Business and Strategy, Vol. 27 Issue 4, 2017, p.485.

6 Mohamed Syazwan Ab Talib, et al., "Emerging Halal Food Market: An Institutional Theory of Halal Certificate Implementation," Journal Management Research Review, Vol. 39 No. 9, September 19, p. 988. es in society including Indonesia and Malaysia ${ }^{7}$ and it reflected on their consumer behavior ${ }^{8}$. They only want to consume and use products with official halal guarantee signs issued by the government. On one hand, the phenomenon shows the level of awareness on the implementation of belief based on Islamic law; on the other hand, it encourages their sensitivity when food or other products come into contact with the elements of haram and halal. ${ }^{9}$

Halal products are last gaining worldwide recognition as a new benchmark for safety and quality assurance. ${ }^{10}$ Products that are produced with Halal certification are readily acceptable by Muslim consumers as well as consumers from other religions. This acceptance is due to the wholesomeness concept of halal, which covers not only the Sharia requirement but also the hygiene, sanitation and safety aspects. To ensure the halal-ness to the consumers, halal standard introduces to the halal industry as well as halal certification from trusted Islamic Organization. ${ }^{11}$ The reality is each country has different practices based on the country's halal requirement. In fact, the involvement of the halal certifying agency also vary by culture and interests. Therefore, Halal Assurance System (HAS) has a key role in halal supply chain system. ${ }^{12}$ Implementation of Halal certification among ASEAN member countries is

7 Andreas Ufen, "Mobilising Political Islam: Indonesia and Malaysia Compared," Journal Commonwealth \& Comparative Politics, Vol. 47 No. 3, July 2009, p. 308.

8 Jusmaliani Jusmaliani and Hanny Nasution, "Religiosity Aspect in Consumer Behaviour: Determinants of Halal Meat Consumption," ASEAN Marketing Journal, Vol. I No. 2, 2013, p. 10.

9 Martin Roestamy, "The Assurance of Halal Products in Legal System of Indonesia, Regional Perspectives on Law and Rights: Where Are We Now and Where are We Heading?", Paper, Proceeding Book of The 2013 Padjadjaran International Legal Conference Series, 22-24 October 2014, p.445.

10 M. van der Spiegel et al., "Halal Assurance in Food Supply Chains: Verification of Halal Certificates Using Audits and Laboratory Analysis," Journal Trends in Food Science \& Technology, Vol. 27 No. 2, October 2012, p.109.

11 Reki Wicaksono Ashadi, "Halal Science: An Introduction", Journal of Halal Reseach, Vol.1 No.1, September 2015, p. 34.

12 Kim Hua Tan et al., "The Impact of External Integration on Halal Food Integrity," Supply Chain Management: An International Journal, Vol. 22 No. 2, March 13 2017, p. 186 
quite unique. Most countries have a role in terms of the establishment and functioning in certification..$^{13}$ Regarding benefit of halal concept, recently halal was transformed from Muslim need to global customer satisfaction. ${ }^{14}$

Every nation has their Halal Standard regulation. ${ }^{15}$ Accordingly, one of the challenges faced by the global Halal Industry is the lack of one unified standard on what exactly Halal is. The idea of this one standard has gained attention by Organization of Islamic Countries (OIC) since last ten years ago. ${ }^{16}$ There are between 500 and 3000 certification agencies around the world of which 80 per cent is from non-Muslim countries. ${ }^{17}$ Standards, technical regulation and procedures for determining conformity are essential to ensure consumer safety and increase transparency of product information and compatibility of products.

The interesting story about this Halal Standard in ASEAN comes from Indofood. The producers of the popular Indo Mie instant noodles, Indofood, is the world's largest instant noodle producer which made the right approach producing high quality products within an acceptable standard to eventually penetrate the European Union market and elsewhere in the west. But not all of Indofood's products, which are all stamped halal, are accepted everywhere. It is accepted in the UK, accepted in Belgium, but not in Malaysia. ${ }^{18}$

13 Baharudin Othman, Sharifudin Md Shaarani, and Arsiah Bahron, "The Potential of ASEAN in Halal Certification Implementation: A Review.," Pertanika Journal of Social Sciences \& Humanities, Vol. 24 No. 1, 2016, p. 23.

14 Rosy Hutani, Reki Wicaksono Ashadi and Lukmanul Hakim, September $30^{\text {th }} 2015$, "Halal Paper Production: A Review", Paper, Proceeding Book The Second Symposium On Global Halal Research, Jakarta: LPPOM MUI, p.13.

15 Siti Salwa Md. Sawari and Mohd Al'lkhsan Ghazali, "Amalan Standard Halal Di Negara-Negara Asia Tenggara," UMRAN - International Journal of Islamic and Civilizational Studies, Vol. 1 No. 1, November 2014, p.12.

16 Mustafa'Afifi Ab Halim and MM Mohd Salleh, "The Possibility of Uniformity on Halal Standards in Organization of Islamic Countries (OIC) Country," World Applied Sciences Journal, Vol. 17 No. 17, 2012, p. 9.

17 Salama, April $6^{\text {th }}, 2015$, WHS: Harmonising Halal Standards Within The ASEAN Region, Retrieved from: http: / /halalfocus.net/whs-harmonising-halalstandards-within-the-asean-region/, accessed on May $10^{\text {th }}, 2017$.

18 Hadi Mahmud, May 5th 2011, A Unified Halal Standard Mooted For Brunei, Malaysia, Indonesia, Retrieved
Southeast Asia is home to more than 250 million Halal consumers and countries like Malaysia, Indonesia and Singapore have had regulations to control the import of Halal-certified products for years. The problem is, the Islamic nations in ASEAN have to come into agreement to one standard for halal. Is it possible, since every country has their own halal standard?

The lack of unified of Halal Standards in ASEAN has also raised production costs for exporting companies, as they must follow different national regulatory standards. By having a unified standard among ASEAN countries, these matters can be addressed and hopefully help minimize the export cost for Halal products especially for food and beverage.

\section{Discussion}

Potential Problems Caused By Halal Standard in the Framework of International Trade

Halal Standard could be identified as a Technical Barriers to Trade which potentially raises trade dispute between export and import country. The Agreement on Technical Barriers to Trade (TBT Agreement) requires that TBT measures do not create unnecessary obstacles to international trade. To this end, Article 2.2 further requires that technical regulations shall not be more trade-restrictive than necessary to fulfil a legitimate objective, taking account of the risks non-fulfilment would create. The legitimate objectives enumerated in Article 2.2 include the protection of human life or health or the protection of environment.

Harmonization of national technical regulations, standards and conformity assessment procedures around international standards and procedures greatly facilitates the conduct of international trade by minimizing the variety of requirements exporters have to meet their export markets. Thus, Article 2.4 of The TBT Agreement requires that where technical regulations are required and relevant international standards exist or their completion is imminent, members must use them as a basis for

from: http://halalmedia.net/unified-halal-standardmooted-brunei-malaysia-indonesia/, accessed on May $15^{\text {th }}, 2017$. 
their technical regulations. However, a technical regulation does not have to be based on relevant international standard if such international standards would be an ineffective or inappropriate means for the fulfillment of the legitimate objectives pursued'.

Implicit discrimination against imports is often found in the context of so-called "product standards". The examples are numerous. A nation which uses Halal standard measures for food and beverage might require all such products to be marked with Halal Certicicates.

In some cases concerning Halal standard as a mandatory instrument for import product, originating country assumed that halal standard is a technical regulation which has been violated The Agreement on Technical Barriers to Trade (TBT Agreement). As a result, this technical regulation causes some problems to trade and leads to dispute among countries. ${ }^{19}$

In applying SPS Agreements and TBT Agreements, the WTO extensively relies on decisions by Codex Alimentarius Commission (Codex). Article 3 of the SPS Agreement provides that a national health standard for food is presumptively legal if it conforms to a standard, guideline, or recommendation established by Codex. A national standard that provides a greater level of protection than Codex is a "trade barrier" unless the WTO decides that the stricker national standard is based on a proper "risk assessment" demonstrating that the Codex standard, guideline, or recommendation do not provide sufficient protection or that the country maintaining the stricter standard has other scientific justification. ${ }^{20}$ Article 2.4 of the TBT Agreement provides that countries shall use Codex or other international standards "except when such international standards or relevant parts would be an ineffective or inappropriate

19 Michele Limenta, et al, "Disabling Labelling in Indonesia: Invoking WTO Laws in The Wake of Halal Policy Objectives", Journal World Trade Review, DOI: 10.1017/ S1474745617000167.

20 SPS Agreement, without Years, without title, Retrieved from: https://www.wto.org/english/tratop_e/sps_e/ spsagr e.htm, accessed on May $10^{\text {th }} 2017$. means for the fulfillment of a legitimate objective. ${ }^{21}$

Codex Committee on Food Labelling (CCFL) under FAO collaboration with WHO had guideliness on Halal since 1997. Within title General Guidelines for Use of the Term "Halal", these guidelines recommend measures to be taken on the use of Halal claims in food labelling. ${ }^{22}$ These guidelines apply to the use of the term halal and equivalent terms in claims as defined in the General Standard for the Labelling of Prepackaged Foods and include its use in trade marks, brand names and business names. The Codex Alimentarius Commission accepts that there might be minor differences in opinion in the interpretation of lawful and unlawful animals and in the slaughter act, according to the different Islamic Schools of Thought. As such, these general guidelines are subject to the interpretation of the appropriate authorities of the importing countries. However, the certificates granted by the religious authorities of the exporting country should be accepted in principle by the importing country, except when the latter provides justification for other specific requirements.

In 2013, forty-two new specific trade concerns rose for the first time in the TBT Committee including four new issues of relevance to the Codex. One of them $f$ concerns about halal food when Brazil's expressed concerns regarding Indonesia's regulation on Halal foods. ${ }^{23}$ This Halal Standard issue sounds like Indonesia's last complaint concerning transparency and discriminatory through technical regulation made by United States on Clove Cigarettes Case. ${ }^{24}$

21 TBT Agreement, without Years, without title, Retrieved from: https://www.wto.org/english/docs_e/legal_e/ 17-.htm, accessed on May $10^{\text {th }} 2017$.

22 WTO, 1997, General Guidelines For Use Of The Term Halal, Retrieved from: http://www.fao.org/docrep/ 005/y2770e/y2770e08. htm accessed on May $5^{\text {th }} 2017$.

23 Report The WTO Secretariat, July 2014, "Joint FAO/ WHO Food Standards Programme Codex Alimentarius Commission", document CAC/37 INF/3, available on website https://docs.wto.org or www.codexalimentarius.org, accessed on April $27^{\text {th }} 2017$.

24 Eva Johan, "Lesson of Implementing Non-Discrimination Principle on Indonesia-US Clove Cigarettes Case", Indonesia Journal of International Law, Vol. 11 Number 1 October 2013, P.106. 
For next some years, this Halal food/Halal standard will be a challanging issue to disscuss in the level of WTO forum which not only ends at a guideline level as Codex Alimentarius. Therefore, it should be a clear Agreement among Muslim nations all over the world for Halal standard measure which become the main provision for all Members. This standard might start from ASEAN community.

\section{Capturing the Development Of Halal Standard In Some ASEAN Nations}

Earlier version of regionalism in Asia was born in Southeast Asia with ASEAN, back in 1967 with five founding member states, Thailand, Malaysia, Indonesia, Singapore and Philippines. Throughout the process of enlargement, ASEAN has now ten members. The Association is run by mutual respect, non-interference in internal affairs, decisions made by consensus and consultative principle. ${ }^{25}$

Asean Economic Community (AEC) is one of three pillars of the ASEAN Community. It seems that legislation provides a framework for ensuring that food, whether imported or otherwise, complies with the regulations and standards for a particular country. For this reason, food regulatory agencies in the Southeast Asia region have evolved regulations to govern food and nutrition labelling in their countries. Most countries have followed the Codex Guidelines in preparing their regulations, namely Indonesia, Singapore, Malaysia, Brunei Darussalam, Laos, Vietnam and Cambodia. ${ }^{26}$

There are some development of Halal Standards/Guidelines. For instance, there is a harmonization of industry practices in some area products such as food and beverage. In National level, some ASEAN country has introduced their Guidelines; MS 1500:2400 Malaysia

25 Si Hong KIM, "East Asian Regionalism: A View from Europe", Paper, International Conference: Recent Evolution in Law in Asia: Globalization and Integration, Law Seminar, Universitas Indonesia, Jakarta, 6-7 August 2015.

26 William Kasapila and Sharifudin MD Shaarani, "Harmonisation of Food Labelling Regulations in Southeast Asia: Benefits, Challenges and Implications," Asia Pacific Journal of Clinical Nutrition, Vol. 20 No. 1, 2011, p.7. standard, PBD 24:2007 Brunei standard, MUIHC-S001/002 Singapore Muis Halal standard and HAS 23000, HAS 23103 and HAS 23201 Indonesia Halal Standard. Then in regional level, there is ASEAN General Guidelines on Preparation and handling of Halal Food. Now, internationally work progress is Global Halal Standards by IHI alliance in collaboration with Islamic Chamber of Commerce and Industry.

Let us analyze some Halal Standard of ASEAN members. First, Singapore: ${ }^{27}$ The Singapore Muis Halal Standards (SMHS) have been developed by the Islamic Religious Council of Singapore (Muis) in collaboration with SPRING Singapore (national standards body) and Muisappointed Halal standards committee comprising religious scholars, industry players and government officials. Their Objectives are: to provide transparent religious and technical guidelines pertaining to Halal certification; to enhance consistency with regard to compliance with Muis Halal certification terms and conditions; and to facilitate trade and other business opportunities.

The SMHS had undergone intensive scrutiny and review from members of the Halal standards committee. Feedbacks were also sought from both local and foreign government bodies, organisations, institutions, scholars, religious and scientific experts, academicians, captains of relevant industries, Halal practitioners as well as members of the general public and considered for inception into this document. Extensive public consultation on the SMHS is necessary to ensure practicality and relevance to the Halal industry. The SMHS comprise 2 components - religious and technical, namely General Guidelines for the Handling \& Processing of Halal Food (MUIS-HC-S001); and General Guidelines for the Development \& Implementation of a Halal Quality Management System (MUIS-HC-SOO2).

\footnotetext{
27 Majlis Ugama Islam Singapura, without Years, Singapore MUIS Halal Standard, Retrieved from http://halal.sg/ Industry/Halal-Standard.html, accessed on $25^{\text {th }} 2017$.
} 
Second, Malaysia. ${ }^{28}$ Malaysia is the only country in the world whereby the government provides full support in promoting the Halal Certification process on products and services. Halal certification bodies in other countries are either developed by the individual provinces or states or backed by their non-governmental organizations (NGOs). Halal Certification provides assurance to all Muslim consumers because it fulfills the Sharia law, which is obligatory for Muslims. To the non-Muslims, Halal products are quality products simply due to the concept of halalan thoyyiban (Halal and wholesome). The Halal standard is recommended to be used together with MS 1480, the standard on food safety according to hazard analysis and critical control point (HACCP) system and MS 1514, on General principles of food hygiene. Thus, products certified Halal by JAKIM are Halal products which are safe to consume or use, nutritious and high quality. The Malaysian certification procedures and both Malaysian Halal Standards MS1500:2009 and MS2200:Part 1:2008 are continuously utilized because they received widespread recognition for maintaining excellence in the field of Halal-compliance. As a result, the Malaysia Halal Logo is recognized and well-accepted worldwide.

Third, Thailand. ${ }^{29}$ The requirements on Halal Standard are covered in the General Guidelines on Halal Products THS 24000:2552 made by The Central Islamic Committee of Thailand. The standard practical guidelines for all organizations are under the rules of halal food accreditation, with the standard features food safety ISO 22005:2007 about General Principles and Basic Requirements for System Design and Implementation and CAC/RCP 1-1969, rev. 4-2003 about Global Standard-General Guidelines on Food Hygiene.

28 HDC, without years, Halal Certification, Retrieved on: http://www.hdcglobal.com/publisher/gwm_halal_certi fication\#sthash.7tcXwEju.dpuf, accessed on April $20^{\text {th }}$ 2017.

29 Central Lab Thai, without years, National Halal Standard Thailand, Retrieved from: http://www.centrallabthai.com/web/uploadfiles/pdf / Agriculture/National Halal_Standard_English.pdf, accessed on May $14^{\text {th }}$ 2017.
Fourth, Indonesia. Halal certification in Indonesia is handled by some institutions. Government bodies responsible for food controlling are Ministry of Agriculture for meat and animal-based foods and National Agency for Foods and Drugs Control (BPOM) for the food packaged product. Meanwhile, Halal certificate is issued by The Indonesian Council of Ulama (MUI) based on an assessment done by The Assessment Institute for Foods, Drugs and Cosmetics The Indonesian Council of Ulama (LPPOM MUI). In Indonesia, Majlis Ulama Indonesia (MUI) exercises an effective monopoly over Indonesia's halal certification scheme ${ }^{30}$ similar to doctrinal compliance in Islamic banking and insurance. MUI supports institution of National Government ${ }^{31}$. Halal standard is established based on a fatwa ${ }^{32}$ of the MUI Fatwa Commission.

Halal Certification Standard of LPPOM MUI based on the Halal Assurance System Concept on Food, Drugs and Cosmetic (HAS 23000), Guidelines of Halal Assurance System Criteria of Slaughterhouses (HAS 23103) and Requirements of Halal Food Material (HAS 23201). ${ }^{33}$ LPPOM MUI has noted some proud achievements. In domestic level, the gait of LPPOM MUI in providing services increases. From 2005 to December 2011, LPPOM MUI issued at least 5896 halal certificates covering up to 97,794 product items from 3561 companies. These figures will be much higher if halal certificates issued by regional LPPOM MUI over 33 provinces in Indonesia are included. ${ }^{34}$ Yet Indonesia now has a

30 Tim Lindsey, "Monopolising Islam: The Indonesian Ulama Council and State Regulation of the "Islamic Economy", Bulletin of Indonesian Economic Studies, Vol. 48 No. 2, August 2012, p. 253.

31 Julian Millie and Linda Hindasah, "Regional Aspects of the Indonesian Ulama Council's Ideological Turn," The Asia Pacific Journal of Anthropology, Vol. 16 No. 3, May 27, 2015, p. 261.

32 Mohamad Abdun Nasir, "The 'Ulamā', Fatāwā and Challenges to Democracy in Contemporary Indonesia," Islam and Christian-Muslim Relations Journal, Vol. 25 No. 4, October 2014, p. 490.

33 LPPOM MUI, without Years, without title, Retrieved from "Halal Products and Halal Requirements in Indonesia" available on website http://www.taiwantrade. com.tw/CH/download/1901057, accessed May $14^{\text {th }}$ 2017.

34 LPPOM MUI, without Years, without title, Halal Certificate Achievements, Retrieved from: http://www.halal- 
new mechanism on Halal Standard and takes so many changes in practices. ${ }^{35}$ The development of Halal standard regulated on Law No. 33 Year 2014 on Halal Product Assurance. This regulation is the main measure to regulate Halal Standard in Indonesia. With this regulation, in 2019, all products distributed and traded spread over Indonesia expected to have halal certificate, since at that time halal certificate will become a mandatory. ${ }^{36}$ Then in the next three years since 2014, 2017 there will be a certain body called Badan Penyelenggara Jaminan Produk Halal (BPJPH) ${ }^{37}$ which becomes an integrated body which issues halal certification. What is part of MUI then? MUI will become a specific institution with their halal standard guidelines to determine whether the product is halal or not. Then fatwa MUI will give recommendation to BPJPH for issuing halal certificates. This BPJPH has authority in issuing Halal Certificate and forming the Halal logo nationwide. Prior to 2017, halal standard mechanism in Indonesia is still run in the same way through LPPOM MUI.

According to Fischer, Malaysia and Singapore play an increasingly important role and hold a special position as countries where the state supported by Muslim agencies, certifies halal products and spaces as well as work processes in ways that are highly commercialized. ${ }^{38}$

\section{What ASEAN have now and then on Halal Standard}

ASEAN countries are among the leading suppliers and importers of halal certified products in the world. Indonesia is the biggest buyer of Malaysia halal food products and Singapore is a major transit hub to the Asia Pacific for halal food with Asia's largest exporters of

mui.org/newMUl/index.php/main/go_to_section/2/31/ page/2, accessd April $20^{\text {th }} 2017$.

35 Diah Setiari Suhodo, 2014, Sertifikasi Halal: Modal Untuk Produk yang Terpercaya, Peluang Usaha Produk $\mathrm{Ha}$ lal di Pasar Global: Perilaku Produsen dalam Memproduksi Produk Halal, Jakarta: LIPI Press, p. 97.

36 Law No. 33 Year 2014 concerning Halal Product Assurance Article 67 (1) jo Article 4

37 Ibid, Article 64.

38 Johan Fischer, "Branding Halal: A Photographic Essay on Global Muslim Markets", Anthropology Today, Vol. 28 No.4, 2012, p. 20. halal products are: 1 . Thailand, 2 . The Philippines, 3. Malaysia, 4. Indonesia, 5. Singapore. For ASEAN, to leverage on the growing opportunities, there is a need for increased cooperation among ASEAN members on production regulateons, certification, standards and required approvals. ${ }^{39}$

Actually, ASEAN have had guidelines for Halal food since 2001, under ASEAN Cooperation in Food, Agriculture and Forestry Major. ASEAN established the "ASEAN General Guidelines on the Preparation and Handling of Halal Food" in the view to further expand intra-ASEAN trade in meat and meat-based products. The Guidelines were prepared based on and in line with the Association of Religious Ministers of Brunei Darussalam, Indonesia, Malaysia and Singapore (MABIMS) Guidelines for Preparation of Food and Drink for Muslims and Codex General Guidelines for Use of the Term "Halal". The Guidelines serves as a practical reference for the food industry in the production and handling of halal food for more effective presence in the regional and international market. ${ }^{40}$

Then ASEAN formatted ASEAN Working Group (AWG) on Halal Food. The ASEAN Working Group on Halal Food is a subsidiary body that coordinates the ASEAN cooperation in halal food, especially in the implementation of ASEAN General Guidelines on the Preparation and Handling of Halal Food. The main tasks of the ASEAN Working Group on Halal Food are: first, to conduct periodic reviews of the processing and marketing of Halal Food in the ASEAN region; second, to develop effective methods of information exchange among ASEAN Member Countries pertaining to Halal Food with the view to facilitating cooperative undertakings in this sector of economy, as well as the eventual coordination and harmonization of ASEAN Halal

39 Pushpanathan Sundram, "ASEAN Community: Regional Strategies to Tap Global Halal Business Opportunities", Paper, Managing Director, Seminar Halal Ingredients Asia, Kuala Lumpur Malaysia, $21^{\text {st }}$ September 2015.

40 ASEAN Cooperation In Food Agriculture and Forestry Major Achievements, without Years, without title, Retrieved from: http://www.asean.org/communities/ asean-economic-community/item/asean-cooperationin-food-agriculture-and-forestry-major-achievements, accessed May $14^{\text {th }} 2017$ 
Food sector regulation and policies; third, to identify areas of cooperation among the ASEAN Member Countries as well as with third countries, groups of countries or international agencies, in order to promote the wide-ranging development of the sector in the ASEAN region; and fourth, to monitor and evaluate the progress made in the implementation of approved projects and activities. ${ }^{41}$

\section{Conclusion}

The results show there are some new challenges for ASEAN to upgrade their guidelines on Halal Food considering most of ASEAN Nations are Muslim people and one single market is heading for ASEAN. ASEAN must prepare a comprehensive measure on Halal standard. ASEAN requires a unified halal standard. The challenge is how ASEAN countries are able to sit down together and find a way to establish one acceptable measure on Halal Standard applicable among ASEAN members.

Halal standard potentially violates the TBT Agreement in the framework of international trade. Thus, the next challenge after unifying Halal standard established, there should be transparent and indiscriminating in designing Halal standard surely by referring to existing International standard (Codex Alimentarius). This is challenging due to Unified Halal Standard ASEAN for not considered as a technical regulation which tends to be non-tariff barriers in international trade.

\section{Suggestion}

ASEAN should not be in denial any longer and start acknowledging the importance of having a common regional Halal Standard in preparation for the establishment of a single international standardization body. Differences in opinion can have detrimental effects on competition and international trade. With a view to harmonize conformity assessment procedures, member countries play a full part within the

41 ASEAN Food Safety Network, Without Years, Matrix For The Development Of ASEAN Common Food Control Requirements available on website http://www.aseanfoodsafetynetwork.net/files/Matrix.pdf, accessd May $14^{\text {th }} 2017$. limits of their resources and as a basis for their technical regulation. As a result, one unified standard on Halal is an obligation.

\section{References}

Ab Halim, Mustafa'Afifi and Salleh, MM Mohd. "The Possibility of Uniformity on Halal Standards in Organization of Islamic Countries (OIC) Country." World Applied Sciences Journal. Vol. 17 No. 17. 2012. Pp. 6-10;

Ab Talib, Mohamed Syazwan et al. "Emerging Halal Food Market: An Institutional Theory of Halal Certificate Implementation". Journal Management Research Review. Vol. 39 No. 9. September 19. Pp. 987-997. DOI: 10.1108/MRR-062015-0147;

ASEAN Cooperation in Food Agriculture and Forestry Major Achievements. Retrieved from website http://www.asean.org/ communities/asean-economic-community/item/asean-cooperation-in-foodagriculture-and-forestry-major-achievements. accessed on May $14^{\text {th }} 2017$.

ASEAN Food Safety Network. Without Years. Matrix For The Development Of ASEAN Common Food Control Requirements. Retrieved from: http://www.aseanfoodsafetynetwork.net/files/Matrix.pdf Accessed May 14 ${ }^{\text {th }} \cdot 2017$;

Ashadi, Reki Wicaksono. "Halal Science: An Introduction". Journal of Halal Reseach. Vol.1 No.1. September 2015. Pp. 32-35;

Central Lab Thai. without years. National Halal Standard Thailand. Retrieved from: http://www.centrallabthai.com/web/u ploadfiles/pdf/Agriculture/National_Ha lal_Standard_English.pdf. accessed on May $14^{\text {th }} \cdot 2017$

Fischer, Johan. "Branding Halal: A Photographic Essay on Global Muslim Markets". Anthropology Today. Vol. 28 No. 4. 2012. Pp. 18-21;

Fitra, Sulhan Abu. "Makanan Menentukan Kualitas Generasi dan Peradaban”. Journal Halal. Vol. XVIII No. 113. Mei-Juni 2015. Pp.32-34;

HDC. Without years. Halal Certification. Retrieved from http://www.hdcglobal.com/ publisher/gwm_halal_certification\#stha sh.7tcXwEju.dpuf. accessed on April $20^{\text {th }} .2017$. 
Hutani, Rosy. Ashadi. Reki Wicaksono and Hakim. Lukmanul. "Halal Paper Production: A Review". Paper. Proceeding Book The Second Symposium On Global Halal Research. LPPOM MUI. Jakarta: September 30 2015 ;

Ismail, Abdul Ghafar and Mohd Noor. Mohd Ali. "Halal Finance and Halal Foods: Are They Falling Apart?". Journal Acta Universitatis Danubius. Economica. Vol. 12 No. 3. 2016. Pp. 113-126;

Johan, Eva. "Lesson of Implementing Non-Discrimination Principle on Indonesia-US Clove Cigarettes Case". Indonesia Journal of International Law. Vol. 11 No. 1. October 2013. Pp.105-111;

Jusmaliani and Nasution, Hanny. "Religiosity Aspect in Consumer Behaviour: Determinants of Halal Meat Consumption." ASEAN Marketing Journal. Vol. I No.2. 2013, P. 10-15.

Kasapila, William and Shaarani, Sharifudin MD. "Harmonisation of Food Labelling Regulations in Southeast Asia: Benefits, Challenges and Implications". Asia Pacific Journal of Clinical Nutrition. Vol. 20 No. 1. 2011, P.1-8;

KIM, Si Hong. "East Asian Regionalism: A View from Europe". Paper. International Conference: Recent Evolution in Law in Asia: Globalization and Integration, Law Seminar. Universitas Indonesia. Jakarta. 6-7 August. 2015;

Limenta, Michele, et al. "Disabling Labelling in Indonesia: Invoking WTO Laws in The Wake of Halal Policy Objectives". Journal World Trade Review. 2017. Pp. 126. DOI: 10.1017/S1474745617000167;

Lindsey, Tim. “Monopolising Islam: The Indonesian Ulama Council and State Regulation of the "Islamic Economy". Bulletin of Indonesian Economic Studies. Vol. 48 No. 2. August 2012. Pp.253-274. DOI: 10.1080/00074918.2012.694157;

LPPOM MUI. Without Years. "Halal Certificate Achievements". Available on: http:// www.halalmui.org/newMUI/index.php/ main/go_to_section/2/31/page/2. accessed April 20 ${ }^{\text {th }} 2017$;

LPPOM MUI. Without Years. Halal Products and Halal Requirements in Indonesia. Retrieved from: http://www.taiwantrade. com.tw/CH/download/1901057. accessed May $14^{\text {th }} 2017$;
Mahmud, Hadi. May $5^{\text {th }}$ 2011. A Unified Halal Standard Mooted for Brunei, Malaysia, Indonesia. Retrieved from: http:// halalmedia.net/unified-halal-standardmooted-brunei-malaysia-indonesia/. accessed on May $15^{\text {th }}$ 2017;

Majlis Ugama Islam Singapura, without Years, Singapore MUIS Halal Standard, Retrieved from: http://halal.sg/Industry/ Halal-Standard.html. accessed on $25^{\text {th }}$. 2017.

Millie, Julian and Hindasah, Linda. "Regional Aspects of the Indonesian Ulama Council's Ideological Turn". The Asia Pacific Journal of Anthropology. Vol. 16 No. 3. May 27. 2015. P.260-281. https://doi. org/10.1080/14442213.2015.1034167.

Muhammad, Nazlida. Vai Shiem Leong. Normalisa Md Isa. "Does the country of origin of a halal logo matter? The case of packaged food purchases". Journal Review of International Business and Strategy. Vol. 27 Issue 4. 2017. Pp. 484-500. DOI: 10.1108/RIBS-062017-0049;

Nasir, Mohamad Abdun. "The 'Ulamā', Fatāwā and Challenges to Democracy in Contemporary Indonesia". Islam and Christian-Muslim Relations Journal. Vol. 25 No. 4. October 2014, Pp.489-505. DOI: 10.1080/09596410.2014.926598;

Othman, Baharudin. Sharifudin Md Shaarani. and Arsiah Bahro. "The Potential of ASEAN in Halal Certification Implementation: A Review". Pertanika Journal of Social Sciences \& Humanities. Vol. 24 No. 1. 2016. Pp. 23-25;

Report The WTO Secretariat. July 2014. “Joint FAO/WHO Food Standards Programme Codex Alimentarius Commission". Document CAC/37 INF/3. available on website https://docs.wto.org or www. codexalimentarius.org. accessed on April $27^{\text {th }}$. 2017;

Roestamy, Martin. "The Assurance of Halal Products in Legal System of Indonesia, Regional Perspectives on Law and Rights: Where Are We Now and Where are We Heading?". Paper. Proceeding Book of The 2013 Padjadjaran International Legal Conference Series. Unpad-PAHAM. Bandung. 22-24 October 2014;

Sabran, Abdurrachman and Noeri. Nuradi. "Sertifikasi Halal". Journal AKSES. Vol. 33 Agustus 2015. Pp.3-5; 
Salama. April 6 ${ }^{\text {th }}$ 2015. "WHS: Harmonising Halal Standards Within The ASEAN Region". Retrieved from: http://halalfocus.net/whs-harmonising-halal-standards-within-the-asean-region/. accessed on May $10^{\text {th }} .2017$.

Salehudin, Imam. "Halal Literacy: A Concept Exploration and Measurement Validation". ASEAN Marketing Journal Vol.II No. 1. June 2010. Pp.10-16;

Salwa, Siti Md. Sawari and Mohd Al'lkhsan Ghazali. "Amalan Standard Halal Di NegaraNegara Asia Tenggara." UMRAN-International Journal of Islamic and Civilizational Studies (EISSN: 2289-8204). Vol. 1 No. 1, November 2014. Pp.12-19. https://doi.org/10.11113/umran2014.1 $\mathrm{n} 1.12$.

Spiegel, M. van der et al. "Halal Assurance in Food Supply Chains: Verification of Halal Certificates Using Audits and Laboratory Analysis". Journal Trends in Food Science \& Technology. Vol. 27 No. 2. October 2012. Pp.109-119. DOI: 10. 1016/j.tifs.2012.04.005;

Suhodo, Diah Setiari. 2014. Sertifikasi Halal: Modal Untuk Produk yang Terpercaya, Peluang Usaha Produk Halal di Pasar Global: Perilaku Produsen dalam Memproduksi Produk Halal. Jakarta: LIPI Press;

Sundram, Pushpanathan. "ASEAN Community: Regional Strategies to Tap Global Halal Business Opportunities". Paper. Managing Director. Seminar Halal Ingredients Asia. Kuala Lumpur Malaysia. $21^{\text {st }}$ September. 2015.

Tan, Kim Hua. et al. "The Impact of External Integration on Halal Food Integrity." Supply Chain Management: An International Journal. Vol. 22 No. 2. March 2017. Pp. 186-199. DOI: $10.1108 / \mathrm{SCM}$ 05-2016-0171;

Ufen, Andreas. "Mobilising Political Islam: Indonesia and Malaysia Compared". Journal Commonwealth \& Comparative Politics. Vol. 47 No. 3. July 2009. Pp. 308-333. DOI: 10.1080/14662040903073761;

WTO. 1997. General Guidelines For Use Of The Term Halal. Retrieved from: http:// www.fao.org/docrep/005/y2770e/y277 0e08.htm. Accessed on May $5^{\text {th. }}$ 2017;

WTO. Without Years. SPS Agreement. Retrieved from: https://www.wto.org/english/ tratop_e/sps_e/spsagr_e.htm. accessed on May $10^{\text {th }} 2017$;

WTO. Without Years. TBT Agreement. Retrieved from: https://www.wto.org/english/docs_e/legal_e/17-.htm. Accessed on May $10^{\text {th }} 2017$. 